OPEN ACCESS

Edited by: Gerald Meininger, University of Missouri, USA

Reviewed by:

Alex M. Dopico,

The University of Tennessee Health

Science Center, USA

Robert Gros,

Robarts Research Institute, Canada

*Correspondence:

Susanne Lage

sml60@medschl.cam.ac.uk

Specialty section: This article was submitted to

Vascular Physiology, a section of the journal

Frontiers in Physiology

Received: 06 November 2016 Accepted: 28 January 2016 Published: 16 February 2016

Citation: Gaccioli F and Lager S (2016) Placental Nutrient Transport and Intrauterine Growth Restriction.

Front. Physiol. 7:40 doi: 10.3389/fphys.2016.00040

\section{Placental Nutrient Transport and Intrauterine Growth Restriction}

\author{
Francesca Gaccioli and Susanne Lager* \\ Department of Obstetrics and Gynaecology, University of Cambridge, Cambridge, UK
}

Intrauterine growth restriction refers to the inability of the fetus to reach its genetically determined potential size. Fetal growth restriction affects approximately $5-15 \%$ of all pregnancies in the United States and Europe. In developing countries the occurrence varies widely between 10 and 55\%, impacting about 30 million newborns per year. Besides having high perinatal mortality rates these infants are at greater risk for severe adverse outcomes, such as hypoxic ischemic encephalopathy and cerebral palsy. Moreover, reduced fetal growth has lifelong health consequences, including higher risks of developing metabolic and cardiovascular diseases in adulthood. Numerous reports indicate placental insufficiency as one of the underlying causes leading to altered fetal growth and impaired placental capacity of delivering nutrients to the fetus has been shown to contribute to the etiology of intrauterine growth restriction. Indeed, reduced expression and/or activity of placental nutrient transporters have been demonstrated in several conditions associated with an increased risk of delivering a small or growth restricted infant. This review focuses on human pregnancies and summarizes the changes in placental amino acid, fatty acid, and glucose transport reported in conditions associated with intrauterine growth restriction, such as maternal undernutrition, pre-eclampsia, young maternal age, high altitude and infection.

Keywords: fetal growth, nutrient allocation, amino acids, glucose, lipids, placental insufficiency

\section{INTRODUCTION}

Intrauterine growth restriction (IUGR) is defined as the failure of a fetus to reach its genetically determined growth potential (Brodsky and Christou, 2004). IUGR affects approximately 5$15 \%$ of all pregnancies in the United States and Europe, but varies widely among developing countries $(30-55 \%$ of infants born in South Central Asia, $15-25 \%$ in Africa, and $10-20 \%$ in Latin America; Kramer, 2003; Saleem et al., 2011). Identification of fetal growth restricted infants is made difficult by the lack of international consensus on the definition and diagnostic criteria for IUGR. In clinical practice detection of IUGR fetuses is based on weight at birth $(<2500 \mathrm{~g})$ or estimated fetal weight $(<10$ th percentile), and by ultrasound assessments of fetal growth (abdominal circumference $<2.5$ th percentile). Moreover, altered Doppler velocimetry indices, such as abnormal umbilical artery waveforms or decreased pulsatility of the middle cerebral artery, suggest abnormalities in the fetal circulation and are indicative of IUGR. Notably, the majority of small-for-gestational age (SGA) babies are constitutionally small and healthy, while only $10-15 \%$ of SGA infants are growth restricted, i.e., with slow growth velocity in utero (Alberry and Soothill, 2007). Likewise, fetuses with falling growth trajectories might be IUGR cases, yet not SGA (Alberry and Soothill, 2007). However, it is not always possible to establish whether an observed low birth weight results from in utero growth restriction and evidence of low birth weight has been often used as a proxy for IUGR. 


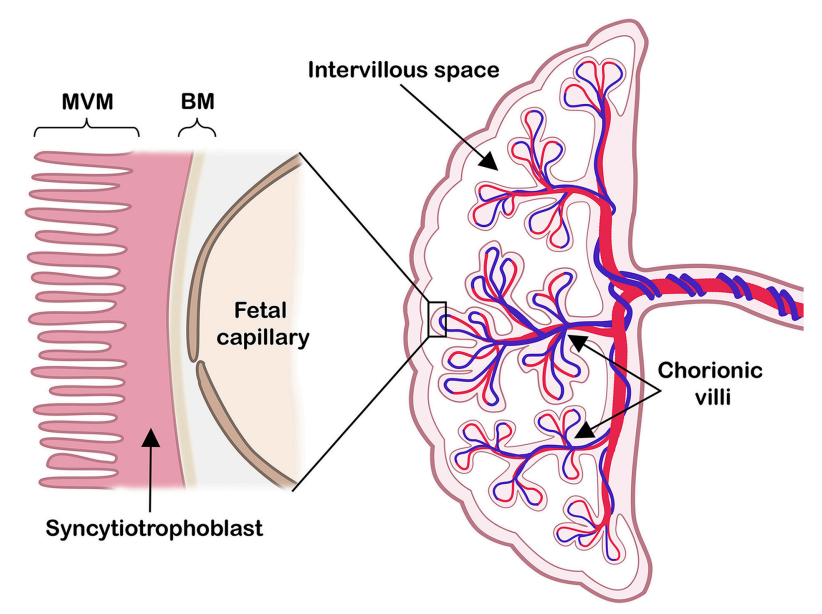

FIGURE 1 | The human placenta at term. Right: a schematic cross-section of the human term placenta with the fetal circulation in umbilical cord and chorionic villi, while maternal blood pools in the intervillous space. Left: representation of the placental barrier, which includes the syncytiotrophoblast layer and the fetal capillary endothelial cells. The two polarized syncytiotrophoblast plasma membranes, the microvillous plasma membrane (MVM) and the basal plasma membrane (BM) are indicated. Modified illustration from Nordisk Nutrition (Lager, 2013), re-printed with permission.

In fact, SGA infants with birth weight below the 2 nd centile for gestational age are at higher risk of being growth restricted (de Jong et al., 1998).

IUGR is associated with an increased risk of stillbirth (Smith and Fretts, 2007), while also a major cause of perinatal morbidity and mortality (Salam et al., 2014). IUGR infants are at higher risk of preterm birth, asphyxia, altered thermoregulation, hypoglycemia, cardiac dysfunction, and infections. Moreover, reduced fetal growth may have adverse consequences on lifelong health, including impaired neuro-developmental progress in childhood and higher risk for metabolic and cardiovascular diseases in adulthood (Barker, 2006; Longo et al., 2013).

\section{PLACENTAL NUTRIENT TRANSPORT}

As the interface between mother and fetus, the placenta mediates exchange of nutrients, oxygen and waste products, thereby ensuring proper fetal growth and development. In term human placenta essentially two cell layers (fetal capillary endothelium and syncytiotrophoblast) separate fetal and maternal circulations. The syncytiotrophoblast has two polarized plasma membranes: a microvillous membrane (MVM) directed toward the intervillous space and a basal membrane (BM) facing the fetal capillaries (Figure 1).

Various factors influence transfer of substances between maternal and fetal circulations. These factors include uteroplacental and umbilical blood flow, concentration gradients of nutrients, as well as the thickness, exchange area, and metabolism of the placenta. The transfer of membrane permeable molecules, such as oxygen and carbon dioxide, is greatly influenced by blood flow and placental structure (Gude et al., 2004). Larger and less membrane permeable substances rely on transporter-proteins to cross the placenta, in a process fueled by ionic gradients (Lager and Powell, 2012).

Both syncytiotrophoblast plasma membranes express several amino acid transporters (Cleal and Lewis, 2008). Amino acid transporters can be categorized according to substrate specificity (system), sequence homology (family), or physiological function (accumulative transporters or exchangers). Accumulative transporters increase intracellular amino acid concentrations by mediating uptake of specific amino acids into the syncytiotrophoblast, usually by co-transporting $\mathrm{Na}^{+}$(e.g., System A, transporting non-essential amino acids such as glycine and alanine, and System $\beta$, transporting taurine). Exchangers alter the intracellular composition without modifying the total amount of amino acids. In general, exchangers substitute non-essential amino acids for essential amino acids (e.g., System L; Broer, 2002). In human placenta, about 20 different amino acid transporters have been identified. Both accumulative and exchanger transporters are expressed in the MVM. Efflux of amino acids from the syncytiotrophoblast toward the fetal circulation is less well characterized. It has been suggested the BM expresses transporters allowing for facilitated diffusion, in addition to the accumulative and exchange transporters (Cleal and Lewis, 2008).

Fatty acids cross the placenta in a multistep process. Lipases associated with the MVM hydrolyze triglycerides into nonesterified fatty acids; the placenta expresses several lipases, including lipoprotein lipase (Herrera and Ortega-Senovilla, 2014). Then the membrane-bound fatty acid transport proteins (FATPs) mediate uptake of long-chained fatty acids (Kazantzis and Stahl, 2011). Five different FATP isoforms are expressed in human placenta (Schaiff et al., 2005). Human placenta also expresses CD36 (fatty acid translocase) (Campbell et al., 1998), a receptor proposed to transport fatty acids or sequester them close to cell membranes in order to facilitate their uptake by FATPs (Schwenk et al., 2008). CD36 and FATPs are expressed in both MVM and BM (Campbell et al., 1998; Dube et al., 2012), suggesting an involvement in syncytiotrophoblast fatty acid uptake and efflux. Further, fatty acids are delivered to different intracellular compartments by fatty acid binding proteins (FABPs) (Smathers and Petersen, 2011). The human placenta expresses four FABP isoforms (Biron-Shental et al., 2007). In addition, a membrane-associated version of FABP, with exclusive MVM localization, has been described (Campbell et al., 1998).

Placental glucose transport occurs by facilitated diffusion through specific glucose transporter proteins (GLUTs), expressed in both plasma membranes of the syncytiotrophoblast (Baumann et al., 2002). Glucose levels are higher in maternal circulation than in fetal circulation (Taricco et al., 2009), resulting in a net glucose transport to the fetus. The GLUT family contains 14 members (Mueckler and Thorens, 2013), of which several are expressed in the placenta (Lager and Powell, 2012). The expression pattern of the GLUTs varies slightly during gestation, but GLUT1 is considered the primary placental transporter of glucose (Baumann et al., 2002). 


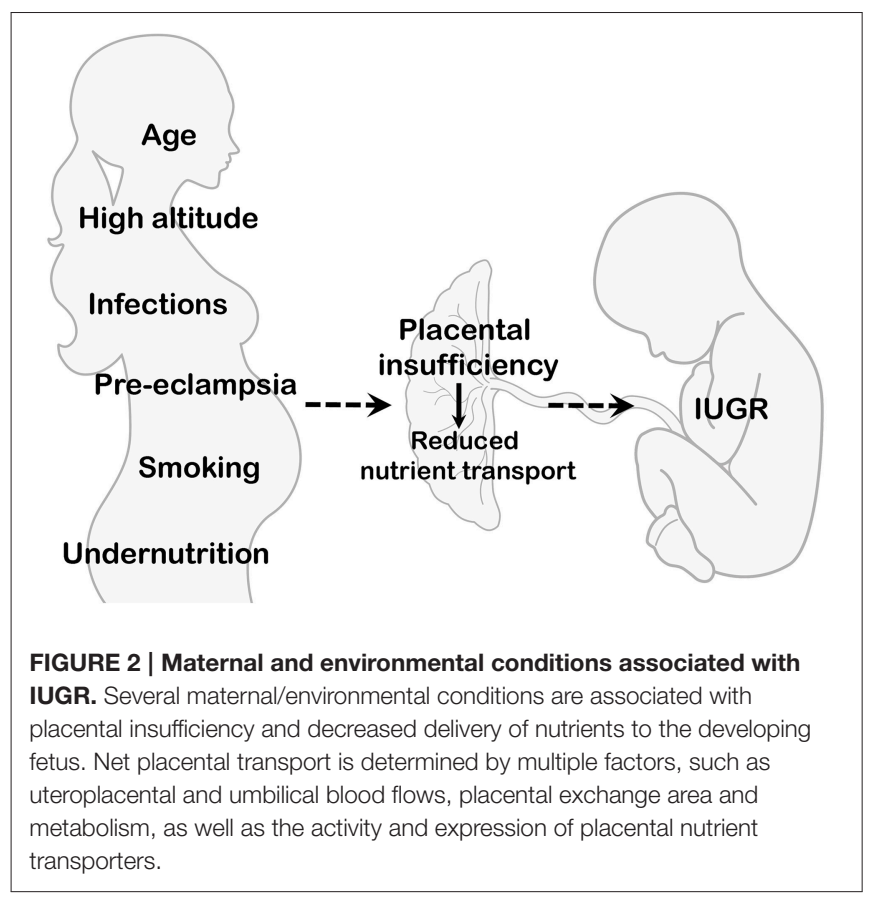

\section{ETIOLOGY OF IUGR}

IUGR is often associated with impaired placental development, structure and morphology, which in turn alter placental function and capacity of delivering nutrients to the fetus (Baschat and Hecher, 2004; Lager and Powell, 2012). Several causes, of environmental, maternal, and fetal origin, can lead to placental insufficiency. These include pregnancies at high altitude, conditions associated with altered uteroplacental blood flow, young maternal age, undernutrition, placental infections and inflammatory processes, cigarette smoke, illicit drugs use, fetal genetic diseases, and congenital malformations (Figure 2). Although optimal materno-fetal exchange of nutrients and gases is of critical importance for fetal growth, studies describing changes in placental transport capacity in the above situations are rarely available in human cohorts and we will briefly summarize them in this review.

\section{Maternal Undernutrition}

Decreased and/or imbalanced maternal nutrient availability is associated with an increased risk of delivering a SGA infant (Stein and Susser, 1975b; Ramakrishnan et al., 2012; Kozuki et al., 2015). The perinatal and long term effects of maternal undernutrition have been extensively studied taking advantage of the "natural experiment" represented by the Dutch famine, a well-defined famine period that lasted approximately 6 months (during the winter of 1944-45) in the German-occupied western provinces of the Netherlands. Studies on pregnancies during the Dutch famine demonstrated that maternal undernutrition in the third trimester inhibits placental growth (Stein and Susser, 1975a).

Maternal undernutrition due to a limited food supply is the main cause of IUGR in developing countries and constitutes a significant problem in industrialized countries where low-income households still experience "food insecurity" (Dowler and O'Connor, 2012). Other causes of low food intake and decreased availability of nutrients for the fetus are severe vomiting after the 16th week of gestation (hyperemesis gravidarum; Snell et al., 1998), short interpregnancy intervals, and adolescent pregnancies.

The impact of maternal undernutrition on fetal growth is at least in part mediated by its effect on the placenta, as this condition is associated with altered placental size, vascular development, endocrine function, and nutrient transport. Although to the best of our knowledge no data is available concerning placental nutrient transport in human pregnancies following maternal undernutrition, useful information are provided by several animal models, including nonhuman primates (Gaccioli et al., 2013). In a baboon model of global maternal nutrient restriction (MNR) during pregnancy, fetal and placental weights were reduced compared with controls. MVM expression of glucose and amino acid transporters (GLUT1, taurine transporter TAUT, SNAT2, LAT1, and LAT2) was downregulated in MNR baboons compared to controls in late gestation (Kavitha et al., 2014). Moreover, decreased transporter expression was paralleled by lower MVM activity of System A and System L in MNR baboons and reduced circulating fetal amino acid concentrations (Pantham et al., 2015).

\section{Pre-eclampsia}

A hallmark of pre-eclampsia is new-onset of hypertension and proteinuria occurring at or after 20 weeks of gestation. IUGR is often an adverse perinatal outcome of pre-eclampsia (Chaiworapongsa et al., 2014) and the two conditions share certain traits, such as inadequate re-modeling of maternal spiral arteries (Brosens et al., 2002). However, the etiologies of IUGR and pre-eclampsia may differ (Villar et al., 2006).

With respect to nutrient levels, alterations in maternal and fetal circulations have been reported in pre-eclamptic pregnancies. Maternal amino and fatty acid blood levels are elevated in pregnancies complicated by pre-eclampsia (Evans et al., 2003; Alvino et al., 2008). Furthermore, total amino acid concentrations are higher and inversely correlate with fetal growth in cord blood from pre-eclamptic pregnancies (Evans et al., 2003). Alterations in cord blood fatty acids levels with preeclampsia have also been reported, suggesting lowered omega-3 fatty acids and elevated monounsaturated fatty acid levels (Roy et al., 2014).

Several studies reported altered activity or mRNA levels of placental nutrient transporters in association with pre-eclampsia. Specifically, placentas from pre-eclamptic pregnancies have a reduced capacity to transport the essential amino acid taurine (Desforges et al., 2013). While placental mRNA levels and activity of System A transporters are not affected, arginine transport across the $\mathrm{BM}$ is increased in placentas from pre-eclamptic pregnancies (Speake et al., 2003; Malina et al., 2005; Shibata et al., 2008). Hence, pre-eclampsia has differential effects on several amino acid transporters found in placenta. Expressions of placental fatty acid transporters are altered by pre-eclampsia as well. Placental mRNA levels of FATP1 and FATP4 are lower in 
pre-eclampsia compared to healthy pregnancies, while CD36 and lipoprotein lipase levels remain unchanged (Laivuori et al., 2006; Wadhwani et al., 2014). Whether protein levels and/or activities are affected similarly remains to be established.

\section{Maternal Age}

Adolescent pregnancies are associated with an increased incidence of low birth weight and SGA infants along with other adverse outcomes and maternal/perinatal mortality (Fraser et al., 1995; Shrim et al., 2011; Weng et al., 2014). Although several socio-demographic factors may play a role in the poor outcomes of adolescent pregnancies, the biological immaturity of these mothers is an independent risk factor (Fraser et al., 1995). It has been proposed that this effect may be due to the maternal young gynecologic age and continued growth during pregnancy. This can impact upon uterine blood supply and govern competition for nutrients between the mother and fetus. However, it is still controversial whether maternal growth is associated with preferential partitioning of nutrients to the still growing mother and, consequently, poor pregnancy outcomes (Stevens-Simon and McAnarney, 1993; Scholl et al., 1994; Frisancho, 1997; Jones et al., 2010).

Work by Hayward and colleagues demonstrated that although placental growth and development were not influenced by maternal age, teenage mothers had lower placental System A activity and reduced mRNA expression of the System A isoforms SNAT1 and SNAT2 compared to adult mothers (Hayward et al., 2011, 2012). This result may partially explain the higher risk of delivering SGA infants in adolescent pregnancies, although in this small UK study cohort there were no significant differences in System A activity between placentas of appropriate-forgestational age (AGA) and those from SGA infants delivered to teenagers. When stratifying adolescent mothers into growing and non-growing, placental System A activity was comparable in the growing teenagers and adult mothers, while non-growing teenagers had significantly lower placental System A activity compared to the other two groups. Such data suggests that maternal growth is not detrimental in nutrient partitioning to the fetus, although it is not completely clear whether the nongrowing adolescents in these studies were skeletally mature or poorly nourished. In the latter scenario a lower placental System A activity could indicate an attempt to spare amino acids for the undernourished mother (Hayward et al., 2011, 2012).

\section{High Altitude}

Risk of reduced birth weight is increased in pregnancies at high altitude (Jensen and Moore, 1997; Krampl et al., 2000; Giussani et al., 2001), but in populations with multigenerational high altitude residence (Andean and Tibetan) birth weight decline is less than populations with shorter residence time (Europens and Han; Moore, 2001; Moore et al., 2011). However, it is still controversial whether impaired oxygen delivery to the fetus contributes to reduced fetal growth in women of European ancestry at high altitude compared to their Andean counterparts. The team led by Moore suggested that a greater increase in uteroplacental blood flow and oxygen delivery, observed as early as 20 weeks of gestation, contributed to the higher birth weight observed in pregnancies of Andean compared to European mothers (Vargas et al., 2007; Wilson et al., 2007). Although Zamudio and co-workers confirmed reduced uterine artery blood flow in high altitude pregnancies of Europeans compared to Andeans, they proposed that maternal oxygen delivery was similar between ancestry groups due to higher maternal hemoglobin content and hematocrit in European mothers (Zamudio et al., 2007). Moreover, umbilical blood flow and absolute oxygen delivery were lower in pregnancies of European women, but their fetuses had increased venous to arterial oxygen extraction (Postigo et al., 2009). These observations led Zamudio and co-workers to exclude that decreased fetal oxygen delivery is associated with differences in fetal growth between the two populations.

Independent of ancestral origin, at high altitude placental weight and size are not altered (Postigo et al., 2009; van Patot et al., 2009). Therefore, these placentas are larger in relation to fetal size, and have increased branching and diameter of fetal capillaries compared to their sea-level counterparts (Ali et al., 1996; Espinoza et al., 2001). Such morphological changes, together with a thinner villous membrane (Jackson et al., 1985), would facilitate placental diffusion in high altitude pregnancies.

To our knowledge no studies on placental amino acid transporter in human pregnancies at high altitude have been performed. In contrast, lower BM expression of the glucose transporter GLUT1 at $>3000$ meters compared to 1600 meters or 400 meters might indicate that placental glucose transport capacity is downregulated in pregnancies at high altitude (Zamudio et al., 2006, 2010). Moreover, Zamudio et al. reported an increased placental glucose consumption at high altitude and suggested that placental anaerobic metabolism spares oxygen but limits glucose availability for fetal growth (Zamudio et al., 2010).

\section{Infection and Inflammation}

Fetal growth may also be impaired by placental inflammation (villitis) and infection. Villitis, described as infiltration of inflammatory cells into placental villi, has been reported to be more common in placentas of SGA or IUGR fetuses than in AGA fetuses (Derricott et al., 2013). As with placental inflammation, certain bacterial and viral infections during pregnancy have been associated with reduced fetal growth (Brocklehurst and French, 1998; Adams Waldorf and McAdams, 2013; Pereira et al., 2014). However, whether villitis, bacterial, or viral infections are associated with altered placental capacity to transport nutrients remains to be determined.

Malaria is an infectious disease caused by the parasitic protozoa Plasmodium. Malarial infection during pregnancy is associated with reduced birth weights (Umbers et al., 2011; Griffin et al., 2012). Moreover, malarial infection affects uterine and umbilical artery blood flows (Griffin et al., 2012) and impairs placental capacity of transporting nutrients to the fetus. Specifically, System A activity is reduced in the placental MVM membrane and glucose transporter GLUT1 expression is lower in the BM in these pregnancies (Boeuf et al., 2013; Chandrasiri et al., 2014). Therefore, changes in blood flows and reduced nutrient transport across the syncytiotrophoblast may contribute to lower birth weights associated with placental malaria infection. 


\section{Alcohol, Smoking, and Cocaine}

Many women consume alcohol during pregnancy (O'Keeffe et al., 2015). While birth weights may not be affected by a low-moderate alcohol exposure, impaired perinatal growth is a characteristic of the fetal alcohol syndrome (O'Leary, 2004; Henderson et al., 2007). In diverse placental in vitro models, ethanol exposure has been shown to reduce taurine (System $\beta$ ) transport (Lui et al., 2014) and transfer of the fatty acids $\alpha$-linolenic and DHA (Haggarty et al., 2002). Contrasting, ethanol does not affect placental glucose or System A amino acid transport (Schenker et al., 1989a).

About $10 \%$ of women in Europe and United States smoke during pregnancy (Baba et al., 2013; Dhalwani et al., 2014; Yang et al., 2014). Maternal smoking is associated with reduced birth weights (Andres and Day, 2000; Baba et al., 2013; Iñiguez et al., 2013; Wang et al., 2014). Similarly, the use of snuff tobacco is also associated with an increased risk of delivering a SGA infant (Baba et al., 2013). Maternal tobacco usage has been shown to have several effects on the placenta, such as reduced mitochondrial function (Bouhours-Nouet et al., 2005), increased double-stranded DNA breaks (Slatter et al., 2014), and lower volume of placental capillaries (Burton et al., 1989). With regards to placental amino acid transport, nicotine reduces the transport of arginine (Pastrakuljic et al., 2000) and inhibits System A amino acid transport (Fisher et al., 1984), but conflicting findings have been reported (Schenker et al., 1989b). Transport of fatty acids appears to not be affected by maternal smoking (Haggarty et al., 2002).

\section{REFERENCES}

Adams Waldorf, K. M., and McAdams, R. M. (2013). Influence of infection during pregnancy on fetal development. Reproduction 146, R151-R162. doi: 10.1530/rep-13-0232

Alberry, M., and Soothill, P. (2007). Management of fetal growth restriction. Arch. Dis. Child. Fetal Neonatal Ed. 92, F62-F67. doi: 10.1136/adc.2005.082297

Ali, K. Z., Burton, G. J., Morad, N., and Ali, M. E. (1996). Does hypercapillarization influence the branching pattern of terminal villi in the human placenta at high altitude? Placenta 17, 677-682.

Alvino, G., Cozzi, V., Radaelli, T., Ortega, H., Herrera, E., and Cetin, I. (2008). Maternal and fetal fatty acid profile in normal and intrauterine growth restriction pregnancies with and without preeclampsia. Pediatr. Res. 64, 615-620. doi: 10.1203/PDR.0b013e31818702a2

Andres, R. L., and Day, M. C. (2000). Perinatal complications associated with maternal tobacco use. Semin. Neonatol. 5, 231-241. doi: 10.1053/siny.2000.0025

Baba, S., Wikstrom, A. K., Stephansson, O., and Cnattingius, S. (2013). Changes in snuff and smoking habits in Swedish pregnant women and risk for small for gestational age births. BJOG 120, 456-462. doi: 10.1111/1471-0528.12067

Barker, D. J. (2006). Adult consequences of fetal growth restriction. Clin. Obstet. Gynecol. 49, 270-283. doi: 10.1097/00003081-200606000-00009

Baschat, A. A., and Hecher, K. (2004). Fetal growth restriction due to placental disease. Semin. Perinatol. 28, 67-80. doi: 10.1053/j.semperi.2003.10.014

Bateman, D. A., and Chiriboga, C. A. (2000). Dose-response effect of cocaine on newborn head circumference. Pediatrics 106:E33. doi: 10.1542/peds.106.3.e33

Baumann, M. U., Deborde, S., and Illsley, N. P. (2002). Placental glucose transfer and fetal growth. Endocrine 19, 13-22. doi: 10.1385/ENDO:19:1:13

Biron-Shental, T., Schaiff, W. T., Ratajczak, C. K., Bildirici, I., Nelson, D. M., and Sadovsky, Y. (2007). Hypoxia regulates the expression of fatty acid-binding proteins in primary term human trophoblasts. Am. J. Obstet. Gynecol. 197, 516.e511-516.e516. doi: 10.1016/j.ajog.2007.03.066
Maternal use of cocaine is also associated with reduced birth weights (Bateman and Chiriboga, 2000; Keegan et al., 2010). In perfused placental cotyledons, cocaine reduces transport of arginine, phenylalanine, and valine (Pastrakuljic et al., 2000), but does not affect transport of alanine and lysine (Krishna et al., 1995). Whether cocaine also affects fatty acid and glucose transporters is currently unknown.

\section{CONCLUDING REMARKS}

Placental transport capacity is one of the pivotal factors affecting the net transfer of nutrients to the developing fetus. Altered placental transport of amino acids, fatty acids, or glucose has been associated with several conditions known to increase the risk of delivering a small or growth restricted infant. With the aim of ameliorating the perinatal and long term outcomes in these infants, further work is needed to understand the mechanisms regulating placental nutrient transport capacity in human pregnancies with IUGR fetuses.

\section{AUTHOR CONTRIBUTIONS}

All authors listed, have made substantial, direct and intellectual contribution to the work, and approved it for publication.

\section{ACKNOWLEDGMENTS}

The authors are grateful to W.G.D. Frederick II and I.L.M.H Aye for valuable comments on the manuscript.

Boeuf, P., Aitken, E. H., Chandrasiri, U., Chua, C. L., McInerney, B., McQuade, L., et al. (2013). Plasmodium falciparum malaria elicits inflammatory responses that dysregulate placental amino acid transport. PLoS Pathog. 9:e1003153. doi: 10.1371/journal.ppat.1003153

Bouhours-Nouet, N., May-Panloup, P., Coutant, R., de Casson, F. B., Descamps, P., Douay, O., et al. (2005). Maternal smoking is associated with mitochondrial DNA depletion and respiratory chain complex III deficiency in placenta. Am. J. Physiol. Endocrinol. Metab. 288, E171-E177. doi: 10.1152/ajpendo.00260.2003

Brocklehurst, P., and French, R. (1998). The association between maternal HIV infection and perinatal outcome: a systematic review of the literature and meta-analysis. Br. J. Obstet. Gynaecol. 105, 836-848. doi: 10.1111/j.14710528.1998.tb10227.x

Brodsky, D., and Christou, H. (2004). Current concepts in intrauterine growth restriction. J. Intensive Care Med. 19, 307-319. doi: 10.1177/0885066604269663

Broer, S. (2002). Adaptation of plasma membrane amino acid transport mechanisms to physiological demands. Pflugers Arch. 444, 457-466. doi: 10.1007/s00424-002-0840-y

Brosens, J. J., Pijnenborg, R., and Brosens, I. A. (2002). The myometrial junctional zone spiral arteries in normal and abnormal pregnancies: a review of the literature. Am. J. Obstet. Gynecol. 187, 1416-1423. doi: 10.1067/mob.2002.127305

Burton, G. J., Palmer, M. E., and Dalton, K. J. (1989). Morphometric differences between the placental vasculature of non-smokers, smokers and ex-smokers. Br. J. Obstet. Gynaecol. 96, 907-915. doi: 10.1111/j.1471-0528.1989.tb03344.x

Campbell, F. M., Bush, P. G., Veerkamp, J. H., and Dutta-Roy, A. K. (1998). Detection and cellular localization of plasma membrane-associated and cytoplasmic fatty acid-binding proteins in human placenta. Placenta 19, 409-415. doi: 10.1016/S0143-4004(98)90081-9

Chaiworapongsa, T., Chaemsaithong, P., Yeo, L., and Romero, R. (2014). Preeclampsia part 1: current understanding of its pathophysiology. Nat. Rev. Nephrol. 10, 466-480. doi: 10.1038/nrneph.2014.102 
Chandrasiri, U. P., Chua, C. L., Umbers, A. J., Chaluluka, E., Glazier, J. D., Rogerson, S. J., et al. (2014). Insight into the pathogenesis of fetal growth restriction in placental malaria: decreased placental glucose transporter isoform 1 expression. J. Infect. Dis. 209, 1663-1667. doi: 10.1093/infdis/ jit803

Cleal, J. K., and Lewis, R. M. (2008). The mechanisms and regulation of placental amino acid transport to the human foetus. J. Neuroendocrinol. 20, 419-426. doi: $10.1111 /$ j.1365-2826.2008.01662.x

de Jong, C. L., Gardosi, J., Dekker, G. A., Colenbrander, G. J., and van Geijn, H. P. (1998). Application of a customised birthweight standard in the assessment of perinatal outcome in a high risk population. Br. J. Obstet. Gynaecol. 105, 531-535. doi: 10.1111/j.1471-0528.1998.tb10154.x

Derricott, H., Jones, R. L., and Heazell, A. E. (2013). Investigating the association of villitis of unknown etiology with stillbirth and fetal growth restriction a systematic review. Placenta 34, 856-862. doi: 10.1016/j.placenta.2013. 07.003

Desforges, M., Ditchfield, A., Hirst, C. R., Pegorie, C., Martyn-Smith, K., Sibley, C. P., et al. (2013). Reduced placental taurine transporter (TauT) activity in pregnancies complicated by pre-eclampsia and maternal obesity. Adv. Exp. Med. Biol. 776, 81-91. doi: 10.1007/978-1-4614-6093-0_9

Dhalwani, N. N., Tata, L. J., Coleman, T., Fiaschi, L., and Szatkowski, L. (2014). A comparison of UK primary care data with other national data sources for monitoring the prevalence of smoking during pregnancy. J. Public Health (Oxf). 37, 547-554. doi: 10.1093/pubmed/fdu060

Dowler, E. A., and O'Connor, D. (2012). Rights-based approaches to addressing food poverty and food insecurity in Ireland and UK. Soc. Sci. Med. 74, 44-51. doi: 10.1016/j.socscimed.2011.08.036

Dube, E., Gravel, A., Martin, C., Desparois, G., Moussa, I., Ethier-Chiasson, M., et al. (2012). Modulation of fatty acid transport and metabolism by maternal obesity in the human full-term placenta. Biol. Reprod. 87, 14, 1-11. doi: 10.1095/biolreprod.111.098095

Espinoza, J., Sebire, N. J., McAuliffe, F., Krampl, E., and Nicolaides, K. H. (2001). Placental villus morphology in relation to maternal hypoxia at high altitude. Placenta 22, 606-608. doi: 10.1053/plac.2001.0696

Evans, R. W., Powers, R. W., Ness, R. B., Cropcho, L. J., Daftary, A. R., Harger, G. F., et al. (2003). Maternal and fetal amino acid concentrations and fetal outcomes during pre-eclampsia. Reproduction 125, 785-790. doi: 10.1530/rep.0.1250785

Fisher, S. E., Atkinson, M., and Van Thiel, D. H. (1984). Selective fetal malnutrition: the effect of nicotine, ethanol, and acetaldehyde upon in vitro uptake of alphaaminoisobutyric acid by human term placental villous slices. Dev. Pharmacol. Ther. 7, 229-238.

Fraser, A. M., Brockert, J. E., and Ward, R. H. (1995). Association of young maternal age with adverse reproductive outcomes. N. Engl. J. Med. 332, 1113-1117. doi: 10.1056/NEJM199504273321701

Frisancho, A. R. (1997). Reduction of birth weight among infants born to adolescents: maternal-fetal growth competition. Ann. N.Y. Acad. Sci. 817, 272-280. doi: 10.1111/j.1749-6632.1997.tb48213.x

Gaccioli, F., Lager, S., Powell, T. L., and Jansson, T. (2013). Placental transport in response to altered maternal nutrition. J. Dev. Orig. Health Dis. 4, 101-115. doi: 10.1017/S2040174412000529

Giussani, D. A., Phillips, P. S., Anstee, S., and Barker, D. J. (2001). Effects of altitude versus economic status on birth weight and body shape at birth. Pediatr. Res. 49, 490-494. doi: 10.1203/00006450-200104000-00009

Griffin, J. B., Lokomba, V., Landis, S. H., Thorp, J. M., Herring, A. H., Tshefu, A. K., et al. (2012). Plasmodium falciparum parasitaemia in the first half of pregnancy, uterine and umbilical artery blood flow, and foetal growth: a longitudinal Doppler ultrasound study. Malar. J. 11:319. doi: 10.1186/1475-2875-11-319

Gude, N. M., Roberts, C. T., Kalionis, B., and King, R. G. (2004). Growth and function of the normal human placenta. Thromb. Res. 114, 397-407. doi: 10.1016/j.thromres.2004.06.038

Haggarty, P., Abramovich, D. R., and Page, K. (2002). The effect of maternal smoking and ethanol on fatty acid transport by the human placenta. Br. J. Nutr. 87, 247-252. doi: 10.1079/BJN2001514

Hayward, C. E., Greenwood, S. L., Sibley, C. P., Baker, P. N., Challis, J. R., and Jones, R. L. (2012). Effect of maternal age and growth on placental nutrient transport: potential mechanisms for teenagers' predisposition to small-forgestational-age birth? Am. J. Physiol. Endocrinol. Metab. 302, E233-E242. doi: 10.1152/ajpendo.00192.2011
Hayward, C. E., Greenwood, S. L., Sibley, C. P., Baker, P. N., and Jones, R. L. (2011). Effect of young maternal age and skeletal growth on placental growth and development. Placenta 32, 990-998. doi: 10.1016/j.placenta.2011. 09.016

Henderson, J., Gray, R., and Brocklehurst, P. (2007). Systematic review of effects of low-moderate prenatal alcohol exposure on pregnancy outcome. BJOG 114, 243-252. doi: 10.1111/j.1471-0528.2006.01163.x

Herrera, E., and Ortega-Senovilla, H. (2014). Lipid metabolism during pregnancy and its implications for fetal growth. Curr. Pharm. Biotechnol. 15, 24-31. doi: $10.2174 / 1389201015666140330192345$

Iñiguez, C., Ballester, F., Costa, O., Murcia, M., Souto, A., Santa-Marina, L., et al. (2013). Maternal smoking during pregnancy and fetal biometry: the INMA mother and child cohort study. Am. J. Epidemiol. 178, 1067-1075. doi: 10.1093/aje/kwt085

Jackson, M. R., Joy, C. F., Mayhew, T. M., and Haas, J. D. (1985). Stereological studies on the true thickness of the villous membrane in human term placentae: a study of placentae from high-altitude pregnancies. Placenta 6, 249-258. doi: 10.1016/S0143-4004(85)80054-0

Jensen, G. M., and Moore, L. G. (1997). The effect of high altitude and other risk factors on birthweight: independent or interactive effects? Am. J. Public Health 87, 1003-1007.

Jones, R. L., Cederberg, H. M., Wheeler, S. J., Poston, L., Hutchinson, C. J., Seed, P. T., et al. (2010). Relationship between maternal growth, infant birthweight and nutrient partitioning in teenage pregnancies. BJOG 117, 200-211. doi: 10.1111/j.1471-0528.2009.02371.x

Kavitha, J. V., Rosario, F. J., Nijland, M. J., McDonald, T. J., Wu, G., Kanai, Y., et al. (2014). Down-regulation of placental mTOR, insulin/IGF-I signaling, and nutrient transporters in response to maternal nutrient restriction in the baboon. FASEB J. 28, 1294-1305. doi: 10.1096/fj.13-242271

Kazantzis, M., and Stahl, A. (2011). Fatty acid transport proteins, implications in physiology and disease. Biochim. Biophys. Acta 1821, 852-857. doi: 10.1016/j. bbalip.2011.09.010

Keegan, J., Parva, M., Finnegan, M., Gerson, A., and Belden, M. (2010). Addiction in pregnancy. J. Addict. Dis. 29, 175-191. doi: 10.1080/105508810036 84723

Kozuki, N., Katz, J., LeClerq, S. C., Khatry, S. K., West, K. P. Jr., and Christian, P. (2015). Risk factors and neonatal/infant mortality risk of small-for-gestationalage and preterm birth in rural Nepal. J. Matern. Fetal Neonatal Med. 28, 1019-1025. doi: 10.3109/14767058.2014.941799

Kramer, M. S. (2003). The epidemiology of adverse pregnancy outcomes: an overview. J. Nutr. 133(5 Suppl. 2), 1592S-1596S.

Krampl, E., Lees, C., Bland, J. M., Espinoza Dorado, J., Moscoso, G., and Campbell, S. (2000). Fetal biometry at $4300 \mathrm{~m}$ compared to sea level in Peru. Ultrasound Obstet. Gynecol. 16, 9-18. doi: 10.1046/j.1469-0705.2000.00156.x

Krishna, R. B., Levitz, M., and Dancis, J. (1995). Lack of effect of cocaine on lysine and alanine uptake in human placental villi or transfer in perfused human placenta. Reprod. Fertil. Dev. 7, 1495-1497. doi: 10.1071/RD9951495

Lager, S. (2013). Placentan aktiv i näringstransporten till fostret. Nordisk Nutrition $3,5-7$.

Lager, S., and Powell, T. L. (2012). Regulation of nutrient transport across the placenta. J. Pregnancy 2012:179827. doi: 10.1155/2012/179827

Laivuori, H., Gallaher, M. J., Collura, L., Crombleholme, W. R., Markovic, N., Rajakumar, A., et al. (2006). Relationships between maternal plasma leptin, placental leptin mRNA and protein in normal pregnancy, pre-eclampsia and intrauterine growth restriction without pre-eclampsia. Mol. Hum. Reprod. 12, 551-556. doi: 10.1093/molehr/gal064

Longo, S., Bollani, L., Decembrino, L., Di Comite, A., Angelini, M., and Stronati, M. (2013). Short-term and long-term sequelae in intrauterine growth retardation (IUGR). J. Matern. Fetal Neonatal Med. 26, 222-225. doi: 10.3109/14767058.2012.715006

Lui, S., Jones, R. L., Robinson, N. J., Greenwood, S. L., Aplin, J. D., and Tower, C. L. (2014). Detrimental effects of ethanol and its metabolite acetaldehyde, on first trimester human placental cell turnover and function. PLOS ONE 9:e87328. doi: 10.1371/journal.pone. 0087328

Malina, A., Daftary, A., Crombleholme, W., Markovic, N., and Roberts, J. M. (2005). Placental system A transporter mRNA is not different in preeclampsia, normal pregnancy, or pregnancies with small-for-gestational-age infants. Hypertens. Pregnancy 24, 65-74. doi: 10.1081/PRG-45780 
Moore, L. G. (2001). Human genetic adaptation to high altitude. High Alt. Med. Biol. 2, 257-279. doi: 10.1089/152702901750265341

Moore, L. G., Charles, S. M., and Julian, C. G. (2011). Humans at high altitude: hypoxia and fetal growth. Respir. Physiol. Neurobiol. 178, 181-190. doi: 10.1016/j.resp.2011.04.017

Mueckler, M., and Thorens, B. (2013). The SLC2 (GLUT) family of membrane transporters. Mol. Aspects Med. 34, 121-138. doi: 10.1016/j.mam.2012.07.001

O’Keeffe, L. M., Kearney, P. M., McCarthy, F. P., Khashan, A. S., Greene, R. A., North, R. A., et al. (2015). Prevalence and predictors of alcohol use during pregnancy: findings from international multicentre cohort studies. BMJ Open 5:e006323. doi: 10.1136/bmjopen-2014-006323

O'Leary, C. M. (2004). Fetal alcohol syndrome: diagnosis, epidemiology, and developmental outcomes. J. Paediatr. Child Health 40, 2-7. doi: 10.1111/j.14401754.2004.00280.x

Pantham, P., Rosario, F. J., Nijland, M., Cheung, A., Nathanielsz, P. W., Powell, T. L., et al. (2015). Reduced placental amino acid transport in response to maternal nutrient restriction in the baboon. Am. J. Physiol. Regul. Integr. Comp. Physiol. 309, R740-R746. doi: 10.1152/ajpregu.00161.2015

Pastrakuljic, A., Derewlany, L. O., Knie, B., and Koren, G. (2000). The effects of cocaine and nicotine on amino acid transport across the human placental cotyledon perfused in vitro. J. Pharmacol. Exp. Ther. 294, 141-146.

Pereira, L., Petitt, M., Fong, A., Tsuge, M., Tabata, T., Fang-Hoover, J., et al. (2014). Intrauterine growth restriction caused by underlying congenital cytomegalovirus infection. J. Infect. Dis. 209, 1573-1584. doi: 10.1093/infdis/jiu019

Postigo, L., Heredia, G., Illsley, N. P., Torricos, T., Dolan, C., Echalar, L., et al. (2009). Where the $\mathrm{O} 2$ goes to: preservation of human fetal oxygen delivery and consumption at high altitude. J. Physiol. (Lond). 587, 693-708. doi: 10.1113/jphysiol.2008.163634

Ramakrishnan, U., Grant, F., Goldenberg, T., Zongrone, A., and Martorell, R. (2012). Effect of women's nutrition before and during early pregnancy on maternal and infant outcomes: a systematic review. Paediatr. Perinat. Epidemiol. 26(Suppl. 1), 285-301. doi: 10.1111/j.1365-3016.2012.01281.x

Roy, S., Dhobale, M., Dangat, K., Mehendale, S., Wagh, G., Lalwani, S., et al. (2014). Differential levels of long chain polyunsaturated fatty acids in women with preeclampsia delivering male and female babies. Prostaglandins Leukot. Essent. Fatty Acids 91, 227-232. doi: 10.1016/j.plefa.2014.07.002

Salam, R. A., Das, J. K., and Bhutta, Z. A. (2014). Impact of intrauterine growth restriction on long-term health. Curr. Opin. Clin. Nutr. Metab. Care 17, 249-254. doi: 10.1097/MCO.0000000000000051

Saleem, T., Sajjad, N., Fatima, S., Habib, N., Ali, S. R., and Qadir, M. (2011). Intrauterine growth retardation-small events, big consequences. Ital. J. Pediatr. 37, 41. doi: 10.1186/1824-7288-37-41

Schaiff, W. T., Bildirici, I., Cheong, M., Chern, P. L., Nelson, D. M., and Sadovsky, Y. (2005). Peroxisome proliferator-activated receptor-gamma and retinoid X receptor signaling regulate fatty acid uptake by primary human placental trophoblasts. J. Clin. Endocrinol. Metab. 90, 4267-4275. doi: 10.1210/jc.20042265

Schenker, S., Dicke, J. M., Johnson, R. F., Hays, S. E., and Henderson, G. I. (1989a). Effect of ethanol on human placental transport of model amino acids and glucose. Alcohol. Clin. Exp. Res. 13, 112-119.

Schenker, S., Johnson, R. F., Hays, S. E., Ganeshappa, R., and Henderson, G. I. (1989b). Effects of nicotine and nicotine/ethanol on human placental amino acids transfer. Alcohol 6, 289-296.

Scholl, T. O., Hediger, M. L., Schall, J. I., Khoo, C. S., and Fischer, R. L. (1994). Maternal growth during pregnancy and the competition for nutrients. Am. J. Clin. Nutr. 60, 183-188.

Schwenk, R. W., Luiken, J. J., Bonen, A., and Glatz, J. F. (2008). Regulation of sarcolemmal glucose and fatty acid transporters in cardiac disease. Cardiovasc. Res. 79, 249-258. doi: 10.1093/cvr/cvn116

Shibata, E., Hubel, C. A., Powers, R. W., von Versen-Hoeynck, F., Gammill, H., Rajakumar, A., et al. (2008). Placental system A amino acid transport is reduced in pregnancies with small for gestational age (SGA) infants but not in preeclampsia with SGA infants. Placenta 29, 879-882. doi: 10.1016/j.placenta.2008.07.001

Shrim, A., Ates, S., Mallozzi, A., Brown, R., Ponette, V., Levin, I., et al. (2011). Is young maternal age really a risk factor for adverse pregnancy outcome in a canadian tertiary referral hospital? J. Pediatr. Adolesc. Gynecol. 24, 218-222. doi: 10.1016/j.jpag.2011.02.008

Slatter, T. L., Park, L., Anderson, K., Lailai-Tasmania, V., Herbison, P., Clow, W., et al. (2014). Smoking during pregnancy causes doublestrand DNA break damage to the placenta. Hum. Pathol. 45, 17-26. doi: 10.1016/j.humpath.2013.07.024

Smathers, R. L., and Petersen, D. R. (2011). The human fatty acid-binding protein family: evolutionary divergences and functions. Hum. Genomics 5, 170-191. doi: 10.1186/1479-7364-5-3-170

Smith, G. C., and Fretts, R. C. (2007). Stillbirth. Lancet 370, 1715-1725. doi: 10.1016/S0140-6736(07)61723-1

Snell, L. H., Haughey, B. P., Buck, G., and Marecki, M. A. (1998). Metabolic crisis: hyperemesis gravidarum. J. Perinat. Neonatal Nurs. 12, 26-37. doi: 10.1097/00005237-199809000-00004

Speake, P. F., Glazier, J. D., Ayuk, P. T., Reade, M., Sibley, C. P., and D'Souza, S. W. (2003). L-Arginine transport across the basal plasma membrane of the syncytiotrophoblast of the human placenta from normal and preeclamptic pregnancies. J. Clin. Endocrinol. Metab. 88, 4287-4292. doi: 10.1210/jc.2003030067

Stein, Z., and Susser, M. (1975a). The Dutch famine, 1944-1945, and the reproductive process. I. Effects on six indices at birth. Pediatr. Res. 9, 70-76.

Stein, Z., and Susser, M. (1975b). The Dutch famine, 1944-1945, and the reproductive process. II. Interrelations of caloric rations and six indices at birth. Pediatr. Res. 9, 76-83.

Stevens-Simon, C., and McAnarney, E. R. (1993). Skeletal maturity and growth of adolescent mothers: relationship to pregnancy outcome. J. Adolesc. Health 14, 428-432. doi: 10.1016/1054-139X(93)90112-3

Taricco, E., Radaelli, T., Rossi, G., Nobile de Santis, M. S., Bulfamante, G. P., Avagliano, L., et al. (2009). Effects of gestational diabetes on fetal oxygen and glucose levels in vivo. BJOG 116, 1729-1735. doi: 10.1111/j.14710528.2009.02341.x

Umbers, A. J., Aitken, E. H., and Rogerson, S. J. (2011). Malaria in pregnancy: small babies, big problem. Trends Parasitol. 27, 168-175. doi: 10.1016/j.pt.2011.01.007

van Patot, M. C., Valdez, M., Becky, V., Cindrova-Davies, T., Johns, J., Zwerdling, L., et al. (2009). Impact of pregnancy at high altitude on placental morphology in non-native women with and without preeclampsia. Placenta 30, 523-528. doi: 10.1016/j.placenta.2009.04.002

Vargas, M., Vargas, E., Julian, C. G., Armaza, J. F., Rodriguez, A., Tellez, W., et al. (2007). Determinants of blood oxygenation during pregnancy in Andean and European residents of high altitude. Am. J. Physiol. Regul. Integr. Comp. Physiol. 293, R1303-R1312. doi: 10.1152/ajpregu.00805.2006

Villar, J., Carroli, G., Wojdyla, D., Abalos, E., Giordano, D., Ba’aqeel, H., et al. (2006). Preeclampsia, gestational hypertension and intrauterine growth restriction, related or independent conditions? Am. J. Obstet. Gynecol. 194, 921-931. doi: 10.1016/j.ajog.2005.10.813

Wadhwani, N., Patil, V., Pisal, H., Joshi, A., Mehendale, S., Gupte, S., et al. (2014). Altered maternal proportions of long chain polyunsaturated fatty acids and their transport leads to disturbed fetal stores in preeclampsia. Prostaglandins Leukot. Essent. Fatty Acids 91, 21-30. doi: 10.1016/j.plefa.2014. 05.006

Wang, N., Tikellis, G., Sun, C., Pezic, A., Wang, L., Wells, J. C., et al. (2014). The effect of maternal prenatal smoking and alcohol consumption on the placentato-birth weight ratio. Placenta 35, 437-441. doi: 10.1016/j.placenta.2014. 04.006

Weng, Y. H., Yang, C. Y., and Chiu, Y. W. (2014). Risk assessment of adverse birth outcomes in relation to maternal age. PLOS ONE 9:e114843. doi: 10.1371/journal.pone.0114843

Wilson, M. J., Lopez, M., Vargas, M., Julian, C., Tellez, W., Rodriguez, A., et al. (2007). Greater uterine artery blood flow during pregnancy in multigenerational (Andean) than shorter-term (European) high-altitude residents. Am. J. Physiol. Regul. Integr. Comp. Physiol. 293, R1313-R1324. doi: 10.1152/ajpregu.00806.2006

Yang, T. C., Shoff, C., Noah, A. J., Black, N., and Sparks, C. S. (2014). Racial segregation and maternal smoking during pregnancy: a multilevel analysis using the racial segregation interaction index. Soc. Sci. Med. 107, 26-36. doi: 10.1016/j.socscimed.2014.01.030 
Zamudio, S., Baumann, M. U., and Illsley, N. P. (2006). Effects of chronic hypoxia in vivo on the expression of human placental glucose transporters. Placenta 27 , 49-55. doi: 10.1016/j.placenta.2004.12.010

Zamudio, S., Postigo, L., Illsley, N. P., Rodriguez, C., Heredia, G., Brimacombe, M., et al. (2007). Maternal oxygen delivery is not related to altitude- and ancestryassociated differences in human fetal growth. J. Physiol. 582, 883-895. doi: 10.1113/jphysiol.2007.130708

Zamudio, S., Torricos, T., Fik, E., Oyala, M., Echalar, L., Pullockaran, J., et al. (2010). Hypoglycemia and the origin of hypoxia-induced reduction in human fetal growth. PLoS ONE 5:e8551. doi: 10.1371/journal.pone.0008551
Conflict of Interest Statement: The authors declare that the research was conducted in the absence of any commercial or financial relationships that could be construed as a potential conflict of interest.

Copyright (๑) 2016 Gaccioli and Lager. This is an open-access article distributed under the terms of the Creative Commons Attribution License (CC BY). The use, distribution or reproduction in other forums is permitted, provided the original author(s) or licensor are credited and that the original publication in this journal is cited, in accordance with accepted academic practice. No use, distribution or reproduction is permitted which does not comply with these terms. 